\title{
Developing complex, mass-customized products in SME networks: Perspectives from co-creation, solution space development, and information system design
}

\author{
Leontin K. Grafmüller \\ Research Associate, HHL Leipzig Graduate School of Management, Center for Leading Innovation \& \\ Cooperation, Jahnallee 59, 04103 Leipzig, Germany, leontin.grafmueller@hhl.de \\ Stephan Hankammer \\ Assistant Professor, Alanus University of Arts and Social Sciences, Chair for Sustainable Management and \\ Entrepreneurship, Villestraße 3, 53347 Alfter, Germany, stephan.hankammer@alanus.edu \\ Affiliated Researcher, RWTH Aachen University, Institute for Technology and Innovation Management, \\ Templergraben 55, 52062 Aachen, hankammer@time.rwth-aachen.de
}

\section{Sarah Hönigsberg}

Research Associate, Chemnitz University of Technology, Chair of Business Information Systems I, Thüringer Weg 7, 09126 Chemnitz, Germany, sarah.hoenigsberg@wirtschaft.tu-chemnitz.de

\section{Hendrik Wache}

Research Associate, Chemnitz University of Technology, Chair of Business Information Systems I, Thüringer Weg 7, 09126 Chemnitz, Germany, hendrik.wache@wirtschaft.tu-chemnitz.de

Received (03.10.2018.); Revised (27.11.2018.); Accepted (05.12.2018.)

\begin{abstract}
Already for nearly three decades, Mass Customization (MC) has been described as a viable business model for companies in diverse sectors. Nonetheless, the introduction and the successful operation of an MC approach is a challenging endeavor for companies of all sizes. In this article, special attention is given to small and medium-sized enterprises (SMEs), which increasingly collaborate in networks to successfully develop complex, mass-customized products. While collaboration allows for pooling several areas of expertise, the cross-organizational development poses challenges in manifold regards. To study these challenges, we set up a network business process model developed with four SMEs from the German high-tech textile industry. Based on the current literature on capabilities for MC, we evaluate the challenges of MC in SME networks detected in our network business process model to underpin the need for further research. In our study, we detail the conceptual analysis of such networkbased scenarios along our process model for three focal areas: (1) co-creation, (2) solution space development, and (3) information system design. We construe the need for further research and derive implications for both academia and practice.
\end{abstract}

Key words: Complexity, co-creation, information system design, new product development, SME, solution space

\section{INTRODUCTION}

Since its inception, mass customization (MC) research has yielded results from multiple perspectives. As MC offers a strategy to provide products, which are both affordable and customized [1], it has been researched extensively and gained heavy interest in both research and practice [2,3]. MC research suggests several capabilities for its realization. Typically, the three capabilities of solution space development, robust process design as well as choice navigation are emphasized [4]. While solution space development refers to the capability to learn about customers' heterogeneous and homogenous needs in order to define customizable and standardized attributes, robust process design denotes the capability to fulfil differentiated customer needs by reusing or recombining organizational resources. Lastly, choice navigation describes customer enabling and supporting as the customer gets a product according to his individual needs [4].

Considering these well-acknowledged capabilities, their suitability appears questionable when looking at small and medium-sized enterprises (SMEs) that aim for developing complex, mass-customized products within a business-to-business (B2B) network for three reasons. First, a complex product is characterized by several customized components, a high number of components, different expertise and experts required as well as the skill needed to develop it [5]. The complexity of products varies with within a spectrum, compared to a highly 
customizable one-of-a-kind boat produced with a high process efficiency [6], customizable shoes with different colored parts are on the simpler side of the spectrum [7]. But existing research mainly focuses on products with a relatively low complexity [8]. Second, typically, there are multiple actors involved in SME networks. However, although early studies focus on MC in SMEs [9], they do not shed light on what capabilities such SME networks require to successfully develop their complex offering. Third, research stresses barriers that hinder successful co-creation in B2B networks $[10,11]$. The need for further research in this regard is particularly relevant as current literature highlights the success of collaborative SME networks [12-15].

Therefore, this study targets the topic of complex MC product development in an SME network. To set out the challenges and research opportunities for this specific SME network context, we created a network business process model using the Business Process Model Notation (BPMN). The process was recorded with four SMEs from the German high-tech textile industry to create an abstract model of co-creation in the network. Technical textiles constitute a high complexity product, because they need to fulfill very specific functional requirements found in other industries, for example heat protection in the aerospace domain [16]. The development of technical textiles is comparable to the chemistry industry, because they are produced by applying techniques and procedures on ingredients, not by recombining modular components [17]. Both, the chemistry and the textile industry are members of the socalled process industries, which are addressed less often in MC research.

To identify the aforementioned challenges, we use the theoretical lens of MC capabilities to structure our analysis and to support the identified need for further research. We detail the conceptual study along our process model for three focal areas: (1) co-creation, (2) solution space development, and (3) information system design. "For each perspective, we provide a discussion of insights gained by detecting difficulties in our particular case setting, contrasted with extant research. Thus, our discussion focuses particularly on deriving a future research agenda.

\section{THEORETICAL UNDERPINNINGS}

In the last three decades, the concept of MC has been subject to research from different management disciplines, such as marketing, operations management, and information systems $[2,18]$. The introduction of the term MC dates back to 1987 and Stan Davis' visionary book "Future Perfect" [19]. According to Davis, MC is present when "the same large number of customers can be reached as in mass markets of the industrial economy, and simultaneously [...] be treated individually as in the customized markets of preindustrial economies". In the early 1990s, MC has been further popularized and developed adding a more operational understanding $[1,20]$. Since the 2000s, there has been an exponential growth of research [2,3]. Today, MC is a broadly accepted economically sustainable concept [4] to deliver affordable products, which better fit the needs of the customers than standard goods and services [21]. In the evolutionary history of manufacturing, $\mathrm{MC}$ is seen as the fifth contingent stage following (1) manual manufacturing, (2) manufactories, (3) industrial mass production, and (4) flexible production of many variants [22].

Depending on the context in which $\mathrm{MC}$ is implemented, companies move to MC from the customization side (increasing the "mass"-aspect) or from the mass production side (increasing the "customization" aspect) [24]. For previous mass producers, customization can increase costs for the complex coordination of producing and marketing goods according to diverging customer needs [23]. For previous craft producers, instead, finding ways to standardize the individual offering, is the core focus [24].

Comparing the introduction of MC in SMEs to large corporations, this reveals a number of additional challenges but also advantages for SMEs. [26] highlight that the implementation of MC is "more important in small and medium enterprises than in larger ones". [25] found that SMEs, besides their lack of resources [27], achieve greater success in implementing the MC approach than large companies.

Thanks to their smaller sizes, SMEs have faster and more flexible processes enhancing information exchange between customer and company. Ad-hoc processes at SMEs allow being more flexible with regard to the changes in customer demand. Moreover, the closer relationship to their customers enables SMEs to establish the co-creation elements of MC [26]. However, the lack of financial resources and technical competencies [28] are key challenges for SMEs, which hinder the successful implementation of MC.

Within the existing MC literature, research on specific capabilities comprises the most important theoretical underpinning for our study. Following the argumentation of the resource-based view [29], MC demands organizational change $[30,31]$ and the acquisition of a set of strategic capabilities [32]. For our study, we mainly follow the proposition of [4], which distinguishes between capabilities for the co-creation process ("choice navigation"), the solution space development process ("solution space development") and the effective and efficient production processes ("robust process design"). For the specific context of MC in SME networks, we detect the following constraints in existing MC literature: (1) The co-creation process is a central element to develop the customized offering successfully. Within an active, creative and social collaboration process, the stakeholders target a joint development [33]. Considering extant MC literature, it appears that the dyad between customer and mass customizer has typically

\footnotetext{
* Instead of looking only at robust process design as the third MC capability, we decided to opt for a broader understanding of managing the digital flow of information to ensure robust processes for the interaction between the network partners.
} 
been at the heart of the research [2]. However, this does not suffice when adding the network factor, including far more stakeholders. An SME network increases complexity and comes with major implications for the cocreation process. We suggest that such processes distinguish external (customer side) and internal (network side) collaboration. In this regard, current B2B research is heavily concerned with cross-organizational, joint value creation processes in B2B networks [11, 34, 35]. However, it has not focused on the MC context. Internal coordination challenges arise with regard to determining the MC offering of the SME network, which relates to the solution space that comprises standardized and customizable product or service components.

(2) According to Tseng and Piller [36], defining the solution space is one of the greatest challenges for $\mathrm{MC}$ companies already on a single-company level. Offering customized products does not mean to offer unlimited choice, but to find the right extent of customization to meet customer demands, while ensuring that every individually defined product is producible in an effective way [31]. For SMEs, it is particularly difficult to define this customization threshold, determining standard components on the one hand and open windows for adapting the solution space continuously on the other hand. This is why this study also explores challenges for SMEs in a network to determine boundaries of the solution space for both the initial offering and its continuous adaption.

(3) The last of the three MC capabilities is the robust process design, which can be defined as the capability of a company to reuse or combine the existing organizational and value chain resources to fulfill differentiated customer needs [4]. These robust processes pose a new complexity through their specific requirements, especially, when they are carried out in an SME network. To handle these requirements, information systems are used [7]. Information systems are systems, in which humans and or machines perform work along a business process using information technology (IT) among other resources to produce a specific product or service [37]. The main usage of information systems in the MC context are the customer integration for value creation and also the successful combination of manufacturing technology, information flow, and product design [38]. The paper at hand focuses on the challenges SME networks face by gaining the ability of robust process design from an (3) information system design perspective.

\section{RESEARCH METHOD}

\subsection{Case study design}

This article presents a contemporary study in a high-tech textile SME network. The companies in the network are on the verge of transitioning from producing one-of-akind technical textiles to being able to mass customize their offerings. We focus on the challenges SME companies face when producing complex MC products in a distributed manner. We used the case study as an empirical method to analyze the phenomenon in the real world [39]. We designed and conducted an embedded case study which is a single case study with multiple units of analysis [39]. We argue for the appropriateness of a single case study approach, as the examined network is considered a common representative of the German high-tech textile industry [40]. To identify the challenges in the network, we opted for a processoriented approach to have a systematic way to examine the phenomenon. We regarded actors, workflows, data and information flow as well as interactions in the network. The data collection in the network included six workshops accompanied by interviews and direct observation with four companies of the German textile industry. This branch is characterized by small batches, niche specialization and high-tech textile applications. The four companies are SMEs at different levels of the value chain, forming a textile network. It contains a weaving company, a knitting company, a textile coating company and a textile finishing company. One of the first two companies produce fabric, which can then be refined by one or both of the latter two companies. Because of the niche specialization, none of the companies can produce a textile by themselves, at least two companies need to work together in order to provide a customer with a textile, which then needs to be confectioned to be fit for use. Hence, the sampling covers different constellations in the value creation network. The companies can act as partners, as well as competitors in the network. The companies' current challenge is to better manage the cross-organizational development of their masscustomized offering, which makes them particularly interesting for our purposes.

In a joint research project, the four companies collaborate with an interdisciplinary research team. The goal is to develop solution approaches for developing complex, mass-customized products within a network. During six workshops, the process model was set up and discussed as a basis for future work. The main task was to detail the current process as nuanced as possible, which has gradually evolved in this network. In particular, we involved the sales departments, the development departments as well as CEOs since they are also involved in developing new offerings.

By creating a process model of the value creation in the network, we applied a design-oriented approach. In accordance with this research paradigm [41], multiple iterations were done for optimization after the initial process recording was conducted. This was performed with members of the network as well as with networkexternal experts of a local textile research institute that come with decades of experience.

\subsection{Business process model notation and conceptual approach}

In order to understand and analyze the status quo in the studied SME network, the process of interaction along the value chain was captured on a conceptual level. The business process was recorded and modeled using BPMN, as a standard language especially at the level of domain analysis [42]. Process modeling is used to reduce the complexity of the real world and to focus the effort on the relevant part of the analyzed process. 
Furthermore, it provides a common base for the communication between all involved stakeholders [43]. With BPMN, business processes are modeled using business process diagrams, which are quite similar to other intuitive graphical modeling techniques. [44] describes the core concepts of BPMN as follows: socalled flow objects are used to describe the flow of a business process, including activities (tasks), events (e.g. start and end of an activity or process) and connectors (gateway), the latter are used to model decision alternatives in the process flow. Swim lanes are used to group activities in pools and lanes. Pools contain a self-contained process, while lanes are used to group activities within different functional areas of a company. Connecting objects are used to define relationships between flow objects, i.e. a sequence flow defines a time sequence between activities, a message flow denotes an information flow between activities or participants via message exchange. Lastly, so-called artifacts (objects, groups, and annotations) can be used to describe specific features. Data objects represent required or generated data and groups can be used to subsume objects i.e. for documentation purposes. The BPMN diagram in this paper is used to study the development of complex MC products and allows identifying the characteristics of the process from different perspectives. Therefore, the graphical notation is vital to examine: (i) the interaction between different process participants, shown as messages between processlanes, (ii) the information flow through the whole process, shown by information objects and (iii) the impact on the overall solution-space-perspective, shown by the complex interaction in the supply chain.

\section{RESULTS: BUSINESS PROCESS MODEL FOR COMPLEX MASS CUSTOMIZATION PRODUCT DEVELOPMENT IN A SMALL AND MEDIUM-SIZED ENTERPRISES NETWORK}

This section provides both an overview and an in-depth description of the recorded process. Figure 1 shows the sequence of the high-level process phases including the iteration loops. Figure 2 shows the entire value creation process in the SME network the paper at hand examines. The process starts with the need expression of the (end) customers and ends with the acceptance of the produced textile by the business customer. To illustrate the interaction between the various actors in the process in more detail, three stakeholder groups are presented across three different pools, not just the SME network itself. The first pool at the bottom of the diagram represents the network with two lanes, with one lane representing the company accepting the order request from the business customer (contractor) and the other lane representing the value chain forming to fulfill the order (value chain). This distinction is important because the contractor bears special responsibilities in the network and plays a steering role for the specific process iteration. The role of the contractor can be assumed by another company in the network for each order and thus for each iteration of the process. The second pool shows the business customer of the network, who is closely connected to the SME network by the co-creational nature of the process, which is recognizable by the multiple communication flows between the two pools. The third pool is the customer of this business customer, who also has to be involved to accommodate its requirements in certain cases. This customer of the customer could already be the end customer, but also another downstream member of the larger textile value chain.

The value creation process is segmented into six subsequent phases (see Figure 1 and bottom part of the Figure 2): (1) Customer Contact, (2) Requirements Analysis, (3) Build Value Chain and Calculation, (4) Prototyping and Feedback, (5) Order and Production, and (6) Outbound Logistics and Project Closure. In the (1) Customer Contact phase the business customer contacts the contractor and the first feasibility check is performed. At this stage there are three possible outcomes: First, it is a known product and can be produced, second, it is a new or modified product that needs to be developed, or third, it is not feasible and the request is rejected and the process ends.

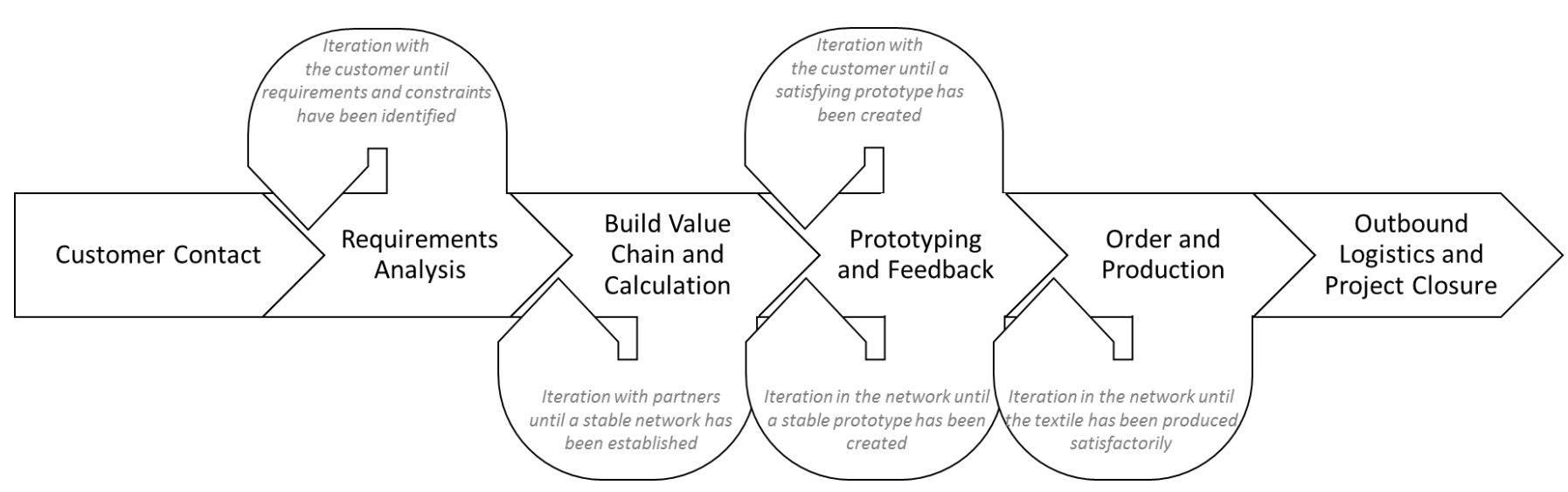

Figure 1. High-level network business process model for MC in SMEs

In case that the product is known, the process shortens and moves on to phase (5) and (6), but in case the product needs to be developed, phase (2) follows next.
This phase is characterized by intense communication to perform the requirements analysis with the business customer and ends with consolidated requirements. 
These requirements are used in the (3) Build-ValueChain-and-Calculation-phase to check the feasibility in the network. An example for a requirement could be that the textile should be fire- and waterproof at the same time. The contractor needs to check if a combination of companies and their machines and services exist, which would be able to develop this fire- and waterproof textile. In case of a stable network, it is possible to carry out and communicate the financial calculation to the business customer. In the following phase (4) Prototyping and Feedback the - until now - purely conceptual prototype can be physically built. When the contractor decides that the requirements are met, in our example a fire- and waterproof textile, the valid prototype is presented to the business customer for feedback, who possibly checks the results with his (end) customer. This phase can lead to iterations to improve the prototype further (Phase 2) or to an order (Phase 5). If the order is placed the (5) Orderand-Production-phase follows, in which the production network is build and the textile is produced. The process ends in the final phase (6) Outbound Logistics and Project Closure, where the business customer receives the textile.

\section{DISCUSSION: DERIVING KEY AREAS OF MASS CUSTOMIZATION RESEARCH FOR SMALL AND MEDIUM-SIZED ENTERPRISE NETWORKS - A THREE-PERSPECTIVE VIEW}

\subsection{A co-creation perspective}

As one element to develop MC products in an SME network, co-creation process denotes the active, creative and social collaboration process between providers and customers that target a joint development [33]. Looking at extant MC literature, the dyad between customer and mass customizer is at the center of interest [2], but the dyadic consideration falls short in analyzing product development processes that span across a network with several stakeholders.

An SME network increases complexity and comes with implications for co-creation. Such processes distinguish external (customer side) and internal (network side) collaboration. In this regard, current $\mathrm{B} 2 \mathrm{~B}$ research is heavily concerned with cross-organizational, joint value creation processes in SME networks [11, 34, 35]. Especially, the management of such processes is crucial for successfully developing products [11, 35, 45].

However, we argue for a shortcoming in extant research regarding the $\mathrm{MC}$ context. Therefore, the process shown in Figure 2 is analyzed in the following through the lens of co-creation.

The center of interest is put on the first three phases described, namely (1) Customer Contact, Requirements Analysis and (3) Build Value Chain. These phases are particularly interesting because co-creation is most intense during these interactions, because they specify the customized offering. Looking at (1) Customer Contact in the given context, we find manifold indications how to design co-creation processes. For example, it is known that customers tend to be confused when given too many options [46], or literature shows how configurators are used to enhance customer's perceived benefit in the customization process [47]. In addition, several studies deliver precise insights of the value components unfolded by the MC offering [48, 49]. However, most of the studies in the MC area are grounded in the consumer context [2], paying far less attention to business customers [24].

We argue that the major difference regarding the cocreation process relates to its value to the customers: while consumers value enjoyment, creativity and product uniqueness, business customers buy for economic rather than emotional reasons [50]. Therefore, for redesigning the customer contact to co-create the MC offering, it is crucial to adapt to those different value components of business customers. In line with recent research from the marketing domain [51, 52], we advocate for a call for research in this regard. Moreover, we argue that these findings are likely to come with major implications for the overall process and, e.g., require adaptations of configurator designs.

The (2) Requirements Analysis with the customer is particularly challenging when product complexity is high, because it often lacks efficiency and efficacy. During the requirement analysis, product details must be explained to the customer, typically in face-to-face settings $[53,54]$. Several studies stress time-consuming and costly processes [19, 53, 54] and incorrect specifications due to high complexity $[59,60]$. This challenges, e.g., the MC capability of choice navigation.

Due to the strong need for face-to-face communication, configurator approaches are rather insufficient, as a high degree of offline interaction is best to face complexity [55]. These processes need to be appropriately designed, for which extant MC research does not hold sufficient results.

Moving to the phase (3) Build Value Chain, we see the most urgent implication as extant MC research neglects the development within networks. For that, two research directions appear fruitful that we integrate with the subsequent phases of the (1) Customer Contact and the (2) Requirements Analysis, as follows. First, Figure 2 suggests that one of the companies is in charge of managing and handling the overall process both externally with the customer and internally with the network.

A deeper understanding of the co-creation process, best practices and organizational structures seems highly promising of how this leading company conciliates the interests and expertise of the different stakeholders, taking into consideration that often this company is the only stakeholder knowing all the parties involved. Second, although possibilities to use configurators seem limited during the phase of requirement analysis [55], configurators or other information systems are wellsuited to facilitate the co-creation process within the network, targeting a smooth, network-internal development process. Recent research on such approaches is rather scant and timely [56]. 


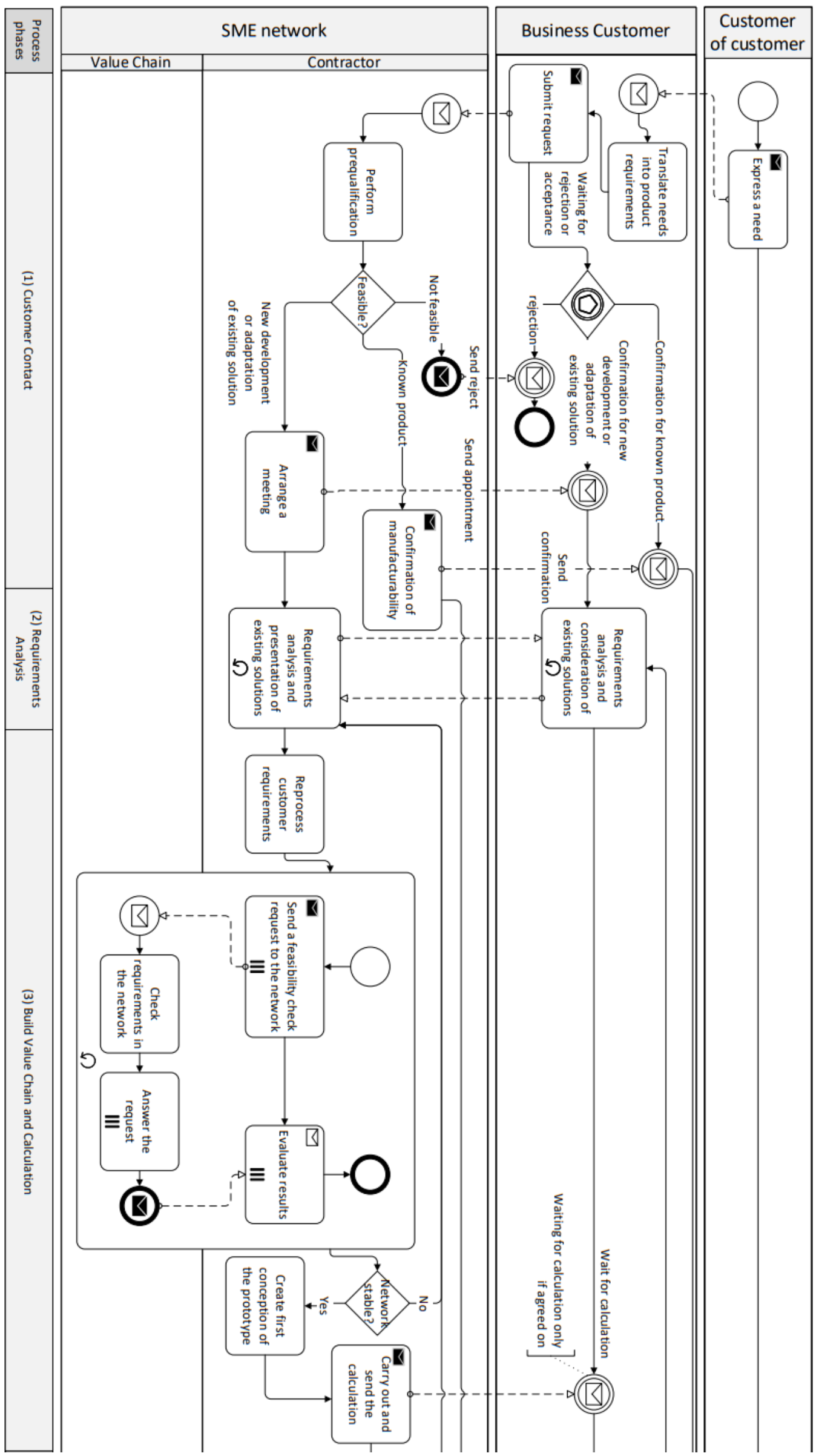

Figure 2. Network business process model for MC in SME. 

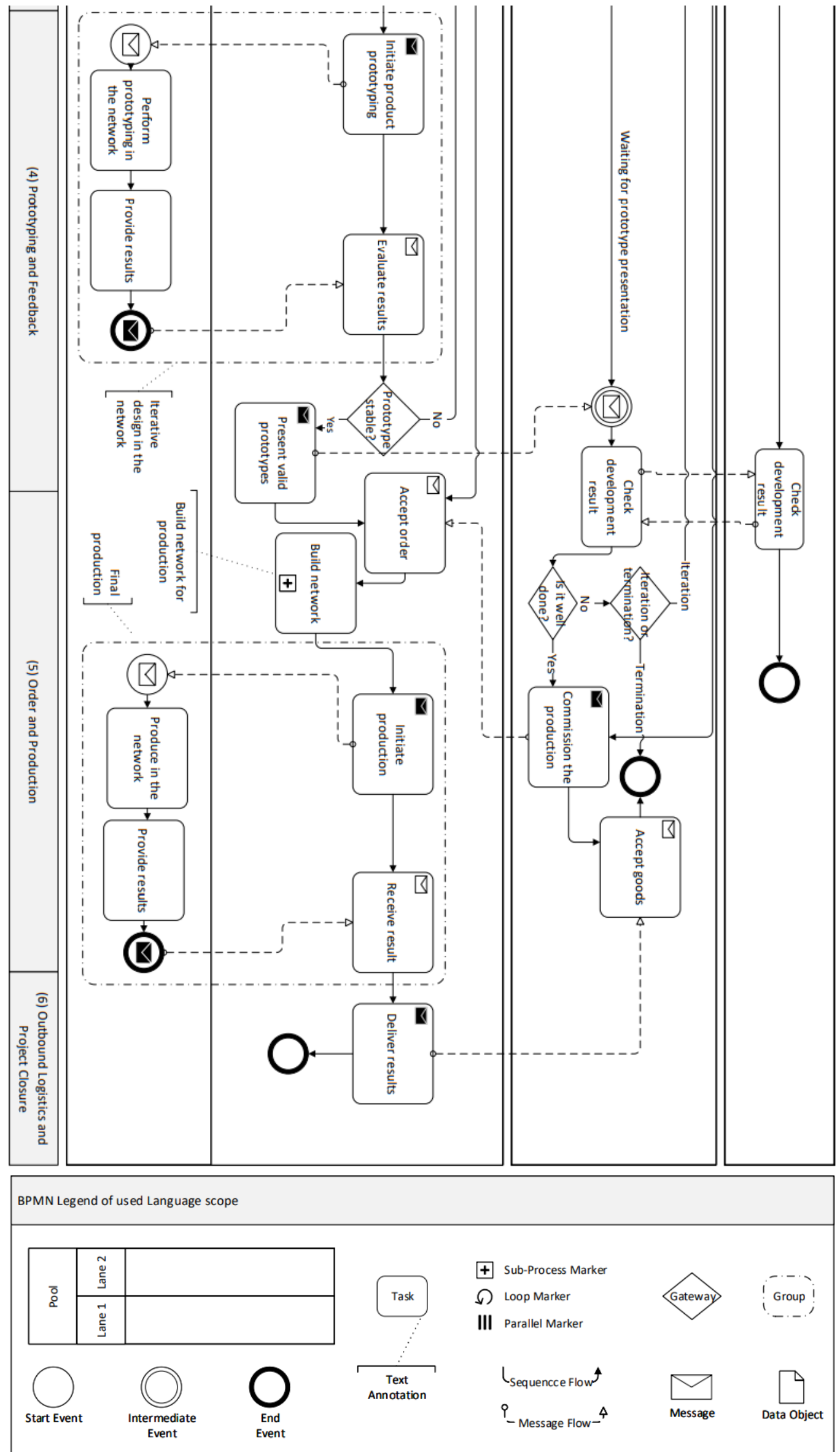

Figure 2. Network business process model for MC in SME (continued). 


\subsection{A solution space perspective}

The second perspective relates to shortcomings of existing literature with regard to developing and using a solution space for MC offerings in an SME network. Already on a single-company level, the successful implementation of $\mathrm{MC}$ is often hindered, because companies "lack the capability to define and set an appropriate solution space" [31]. A solution space is "the pre-existing capability and degrees of freedom built into a given manufacturer's production system" [57]. The task of developing such a solution space is "clearly a managerial decision" [58] and a prerequisite for any SME network which jointly develops an MC approach. MC literature stresses that the other two capabilities, robust process design and choice navigation, depend on the previously defined solution space [64]. Thus, also the outcome of the co-creation process with every single customer modeled in the BPMN diagram fundamentally depends on the previous definition of the solution space.

While existing literature clearly underlines the importance of solution space development, research on this core capability is very limited [61]. Thus, our call for further research on solution space development in SME networks also includes research on this capability in general. According to [61-63], solution space development is divided into two phases, which differ according to the progress in the product development process: the initial solution space development and the adaptive solution space development.

The initial development describes the period before market launch, in which a company defines all the product and service possibilities or variations that it would like to offer at the time of its market launch [58]. The definition of the initial solution space requires great care because the heterogeneity of customer needs produces a large range of product variations whose implementation is not economically feasible [57]. In an SME network, it is not only one company that needs to determine its offering, but also several companies with several mutually dependent processes. In MC literature, it is not yet described, how SMEs can be supported to jointly develop an initial solution space. In our case study in the German high-tech industry, however, developing a joint solution space has been observed as a particularly difficult task.

For the SMEs, defining the solution space is a core challenge, because the job of each company is not only to define what it is able to produce and which product characteristics work well together, but also what each company really wants to produce. All companies in the network must limit the solution space and carefully determine, which product variations it wishes to offer to the customer. At this point, the decision is also made, which product properties remain constant as standard offers, and which can be varied according to customer needs [65]. In business-to-customer-markets, the solution space is usually understood as a selection menu of options, from which customers can choose to create a product according to their individual needs [66]. However, for SMEs in a B2B network with highly complex products, transferring the solution space into simple selection menus is not easily feasible as the complexity is difficult to be sufficiently reduced and full autonomy for choosing between pre-defined options cannot be given to the customer (see also Section 5.1, in which the need for offline interaction is explained). Instead, our analysis of the BPMN reveals that other forms of simplifying the representation of the solution space to the sales manager need to be developed.

The adaptive solution space development describes the period after the market launch and the competence to continuously adapt or improve an existing solution space to current customer requirements and market conditions $[61,62]$. For leveraging MC efficiency in crossorganizational development, it is important that the network does not develop a product or service offering for a new customer from scratch but instead explores whether and how the individual product can be developed based on existing product architectures and corresponding production and sales processes [22]. In a network such as a service-oriented textile network, it is rather a combination of existing modular processes of the network partners than a product architecture.

The BPMN diagram helps to clarify when and how the solution space development capability is needed. Already in the (1) Customer Contact phase, the first feasibility check is performed with the main aim to discover, whether the desired product is within the range of the existing solution space (production is directly feasible) or at least within the scope of previously defined spots for adaptation (production is not immediately feasible, but the solution space can be easily adapted). If the desired product is outside the scope of the solution space (and outside the previously defined area of adaption), the request must be rejected and the process ends.

Also in the later phase (4) Prototyping and Feedback, the results of the feasibility checks need to be used in the definition and adaptation of the solution space. It is important to notice that the current processes of the SME network reveals that companies currently focus on "known products" instead of "known feasible configurations of a solution space" (see phase (1)). For complex products it is, thus, rather difficult for SMEs to follow the solution space logic strictly. Further research is needed to explore barriers for consequently using the solution space logic.Finally, existing literature stresses that solution space development always contains a market research perspective [4].

Only when a company understands the specific needs of each individual customer, it is able to develop a suitable solution space and to assess the costs and complexity of this solution space [67]. Thus, it is a continuous job of all members of an SME network to finding out what customers want and collecting all this information to form the solution space. In research, recommendations for researching individual needs within a network of different value partners have not been described yet and constitutes a core challenge in our SME network case. 


\subsection{An information system design perspective}

The third perspective focuses on the critical requirement called robust process design, which describes the capability of a company to reuse or combine the existing organizational and value chain resources to fulfill differentiated customer needs [4]. This capability can be further divided into process modularity, flexible automation and adaptive human capital.

Customer needs cannot be directly translated to process variations. [68] use a domain framework to illustrate that in order to meet customer needs a product platform provides functionality and has a corresponding process platform, which in turn provides technical feasibility for design changes through process variations. These variations can be realized by treating the value chain processes as segments, which provide variability through recombination and thus create modular processes [4]. A clear definition of valid process inputs and outputs is needed to be able to recombine these process segments. This however is problematic in SME networks, because by providing these concise conditions for modular processes, which can be seen as interfaces between different companies, information about a company's capabilities is shared. Companies need to walk a fine line by sharing just enough information to enable modular processes within their network, while not giving away their competitive advantage by oversharing information regarding to their individual capabilities. An example would be the width of a panel of fabric which the machinery at a company can handle. The importance of standardized interfaces for process segments can be seen in Figure 2, where the contractor selects companies for the value chain depending on their capabilities and the individual compatibilities of the segments during the building of the value chain. The contractor is thereby configuring the value chain. The research by Zhang supports our identified challenges in regards to distributed configuration and stresses the importance of further research for example in the knowledge acquisition in networks [69].

In the past automation was synonymous with rigidity, but nowadays modern technologies allow for more flexibility while still providing automation. This is realized through adaptive systems, which can react on environmental changes or accommodate for personalized experience in the case of the entertainment industry [4]. Information systems are the enablers for modern MC, because they can share information automatically or analyze data and react accordingly [7]. Their capabilities in the context of $\mathrm{MC}$ are vast, they can be used by both customers and companies, they provide customer decision support but also assist in pricing, design, production planning and the gathering of production process information [2]. Leveraging the possibilities of information systems is further complicated by the number of participants in the SME network. The more companies exist in the network, the more effort is required to unify the IT landscape required for information exchange. Most SME companies use different and incompatible systems, partly because they rely on individual software solutions, have lots of internal media discontinuities or even base their workflows on paper and telephones. These circumstances pose a big problem, especially during periods of higher interaction between the companies of the SME network discussed in this paper. These interaction-intensive periods are characterized by complex communication patterns and occur in the process in the phases (3) Build Value Chain and Calculation, (4) Prototyping and Feedback, and (5) Order and Production. Examples for problems emerging from the heterogeneity of employed information systems are incomplete information transfer from the requirements analysis to the production stage or inefficient communication during collaborative prototyping. Incomplete transfer of information in the network have severe effects on efficiency in our observed network, however literature often suggest, that configurators are used in integrated IT landscapes with a high degree of automation [2, 70].

Automation has its limits though; it fortunately does not make human involvement unnecessary, on the contrary. The automated, modular processes of a well operating MC company still need humans, which need the appropriate skills to make mass customization work. [71] portrays an early successful attempt of a company leveraging mass customization by describing the approach of the National Industrial Bicycle Company of Japan. That company established a rotation of workers in order to broaden the knowledge and skill base to enable the company to develop new manufacturing capabilities for their MC approach. In our case this aspect is complicated by the field setting, where four independent companies interact to achieve competitive advantages against their competition. They serve different roles in this constellation, some are suppliers, some are service providers and some partly offer identical contributions within the value chain. A rotation of workers is not ideal for these companies because that would provide valuable insight into their individual competitive advantages - albeit it would possibly strengthen the SME networks competitive advantage. Recent research in this area supports our identified challenge, that a proper knowledge transfer is a key to $\mathrm{MC}$ adoption in B2B networks [72].

Looking at the ability of robust process design from an information system design perspective, there are three promising research directions. In order to be able to (1) ensure modular processes in an SME network effectively and efficiently, an IT-based implementation of the value creation process and its process steps should be examined. A conceptual information model describing process and process steps with clean interfaces and input-output relationships seems to be a promising next step. To be able to use (2) automation and the associated advantages in SME networks, continuous information flows should be created. In the opinion of the authors, this can be achieved by reducing media discontinuity and increasing the general degree of digitization. As digitization progresses, large amounts of data are created in the value creation process. These provide an opportunity to conduct subsequent data 
analysis within the network, which leads to new research perspectives. From an information system design perspective the task of (3) involving humans into the value creation can be facilitated in many ways.

Especially in the discussed highly specialized SME network, which develops complex products, the knowledge transfer between employees across companies is vital. Research on IT supported concepts for sharing data, information, and knowledge in an appropriate way seems to be a promising starting point to reach an inter-organizational platform for cooperation and knowledge transfer in SME networks. Although collaboration platforms are discussed in general, to the best of the authors' knowledge there is no concept to address this inter-organizational integration in the domain of $\mathrm{MC}$ to this extent.

\subsection{Construing further research}

Based on the three perspectives, Table 1 presents the summary with the research fields that need to be involved to solve the identified tasks based on the BPMN in this study.

Table 1. Derivation of further research from three perspectives

\begin{tabular}{|c|c|c|c|}
\hline $\begin{array}{l}\text { The need for further research is derived from the three-sided elaborations on the development } \\
\text { of complex, mass-customized products in SME networks presented above. The goal is to } \\
\text { formulate directions for future research while pointing at the involved research fields. As a } \\
\text { result, we argue for strong interdisciplinarity to tackle the topics. } \\
\text { The table reads as follows. It starts off with the overarching research question from the } \\
\text { respective domain, followed by the tasks from this perspective. The columns on the right } \\
\text { indicate the research fields that need to be involved to target the task. }\end{array}$ & 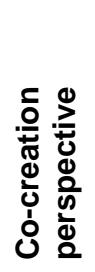 & 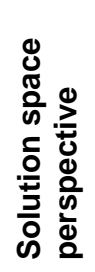 & 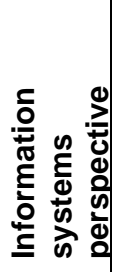 \\
\hline \multicolumn{4}{|l|}{ How can companies leverage the co-creation within an SME network? } \\
\hline \multicolumn{4}{|l|}{$\begin{array}{l}\text { Exploit information systems opportunities to increase efficiency and efficacy of co-creation } \\
\text { within the network }\end{array}$} \\
\hline \multicolumn{4}{|l|}{ Understand how the leading company of the network co-creates the portfolio } \\
\hline \multicolumn{4}{|l|}{$\begin{array}{l}\text { Develop approaches to avoid incorrect specification during requirement analysis with the } \\
\text { customer, enabling the network to participate throughout the process }\end{array}$} \\
\hline \multicolumn{4}{|l|}{$\begin{array}{l}\text { How can companies use the solution space logic to leverage both standardization and } \\
\text { individualization potentials within an SME network? }\end{array}$} \\
\hline \multicolumn{4}{|l|}{$\begin{array}{l}\text { Engage in joint market research activities to explore joint unique selling propositions and } \\
\text { possibilities to skim the willingness-to-pay for heterogeneous customer needs }\end{array}$} \\
\hline \multicolumn{4}{|l|}{ Exploit standardization potentials of clearly defining and limiting individualization possibilities } \\
\hline \multicolumn{4}{|l|}{$\begin{array}{l}\text { Develop a joint understanding of open spots for adaptation and extension of the joint product } \\
\text { offering }\end{array}$} \\
\hline \multicolumn{4}{|l|}{$\begin{array}{l}\text { How can companies use information systems effectively to foster MC within an SME } \\
\text { network? }\end{array}$} \\
\hline \multicolumn{4}{|l|}{$\begin{array}{l}\text { Explore a method to create an IT-supported modular process-based solution space in the } \\
\text { network }\end{array}$} \\
\hline \multicolumn{4}{|l|}{$\begin{array}{l}\text { Create an approach to unify or integrate heterogeneous IT landscapes across the network in } \\
\text { a cost-efficient way }\end{array}$} \\
\hline $\begin{array}{l}\text { Investigate an IT-based approach of cross-company knowledge transfer and exchange for co- } \\
\text { creation within the network }\end{array}$ & & & \\
\hline
\end{tabular}

\section{CONCLUSION}

In this paper, we derived a process model that describes the current processes of an SME network that jointly targets individual need satisfaction of B2B customers.
To answer the question of which challenges are SME networks facing when transitioning towards producing complex products using an MC approach, we used the lens of MC capabilities on this descriptive process model to derive key areas of $M C$ research that need to be extended to the perspective of SME networks. 
Additionally, we also detected other focal points that require further attention in $\mathrm{MC}$ research such as highly complex products, and process-oriented companies with a solution space based on modular process instead of modular product architectures.

Based on the analysis of the BPMN diagram of the SME network processes for $\mathrm{MC}$ offerings, we argue that there is a strong need to tackle the topic of SME networks with an interdisciplinary approach, because the three focal perspectives are highly interwoven.

From the co-creation perspective, we showed with the process model that there is one leading company of the network. Given that, this company is in charge of handling both the customer and the internal network. On the one hand, we argue for a study on how this company manages the SME network on an organizational level, shedding light on drivers and barriers. On the other hand, the co-creation process needs enrichment by both the solution space and information system design perspective. Especially, the leading company is likely to face challenges when co-creating the solution space, as it requires to deeply understand the capabilities of each network company. Furthermore, we see great potential to support the co-creation processes within the network with information systems.

Also from a solution space perspective, we argue that SME networks need to be supported with tools and methods to explore not only what their customers want, but also what they do not want (see Table 1). For exploiting the benefits of MC, companies need to define clear boundaries for their offerings, but also wellselected spots for continuously enabling adaptation of the solution space. Transparency about the offerings of each network company is thus one of the core challenges for SME networks offering MC products. Research should support such networks with developing guidelines in the sense of "modular construction kits". Moreover, we revealed that SMEs have difficulties in strictly following the solution space logic. Instead, the SMEs think within the frames of "known products" instead of "known configurations within a solution space". Future research needs to propose comprehensive approaches to enable SMEs to introduce the MC logic consistently.

For the information system design perspective focusing on the robust process design, we described three main research areas. In the first area, we advocate an ITsupported mapping of the modular processes across the entire network in order to enable an efficient process configuration of short-term value chains. In the second area, we emphasized the importance of the general digitalization in the SME network to enable the companies to use automation and data analytics. Finally, in the third area we argue that an inter-organizational knowledge transfer platform addresses the challenges of developing products in highly specialized industries.

With our article, we create a basis for further research in manifold areas, such as SME networks, complex MC products, and MC capabilities derived from the analysis of an SME network in the German high-tech textile industry. Nonetheless, our article is not free of limitations. First, we only looked at a single case within a specific industry. Thus, our findings cover particularities that might not be relevant in other sectors. Second, the SME network does not cover all levels of a textile value chain. Involving additional partners, such as yarn manufacturing or confectioning could have affected our findings. Moreover, we focused only on three perspectives as our lens. Finally, our BPMN approach is merely process-oriented and thus further research should include a broader case study to cover more than processes and the three perspectives on MC in SME networks. The findings of this paper will be integrated in the embedding research project, PROFUND, with the goal of fostering $\mathrm{MC}$ in an SME network regarding $\mathrm{B} 2 \mathrm{~B}$ co-creation, distributed solution space development and robust processes supported by information systems.

\section{ACKNOWLEDGEMENT}

The research described in this paper was supported by a grant from the German Ministry for Research and Education (BMBF), project name: PROFUND (Processoriented configuration of value creation in textile networks for mass customization in SME), FKZ: 03ZZ0618.

\section{REFERENCES}

[1] Pine, B.J. (1993), "Making mass customization happen: Strategies for the new competitive realities", Planning Review, Vol. 21, No. 5, pp. 23-24.

[2] Fogliatto, F.S., Da Silveira, G. and Borenstein, D. (2012), "The mass customization decade: An updated review of the literature", International Journal of Production Economics, Vol. 138, No. 1, pp. 14-25.

[3] Da Silveira, G., Borenstein, D. and Fogliatto, F.S. (2001), "Mass customization: Literature review and research directions", International Journal of Production Economics, Vol. 72, No. 1, pp. $1-13$.

[4] Salvador, F., de Holan, P.M. and Piller, F. (2009), "Cracking the code of mass customization", MIT Sloan Management Review, Vol. 50, No. 3, pp. 71-78.

[5] Hobday, M. (1998), "Product complexity, innovation and industrial organisation", Research Policy, Vol. 26, No. 6, pp. 689-710.

[6] Kristianto, Y., Helo, P. and Jiao, R.J. (2015), "A system level product configurator for engineer-to-order supply chains", Computers in Industry, Vol. 72, pp. 82-91.

[7] Dietrich, A.J., Kirn, S. and Sugumaran, V. (2007), "A ServiceOriented Architecture for Mass Customization-A Shoe Industry Case Study", IEEE Transactions on Engineering Management, Vol. 54, No. 1, pp. 190-204.

[8] Haug, A., Ladeby, K. and Edwards, K. (2009), "From engineer-toorder to mass customization", Management Research News, Vol. 32, No. 7, pp. 633-644.

[9] Svensson, C. and Barfod, A. (2002), "Limits and opportunities in mass customization for "build to order" SMEs", Computers in Industry, Vol. 49, No. 1, pp. 77-89.

[10] Mosig, T., Grafmüller, L.K. and Lehmann, C. (2017), "Business Model Patterns of B2B Mass Customizers: The Case of German Textile SMEs", International Journal of Industrial Engineering and Management, Vol. 8, No. 3, pp. 99-110.

[11] Chowdhury, I.N., Gruber, T. and Zolkiewski, J. (2016), "Every cloud has a silver lining - Exploring the dark side of value cocreation in $B 2 B$ service networks", Industrial Marketing Management, Vol. 55, pp. 97-109.

[12] Driessen, P.H. and Hillebrand, B. (2013), "Integrating Multiple Stakeholder Issues in New Product Development. An Exploration", Journal of Product Innovation Management, Vol. 30, No. 2, pp. 364-379.

[13] Vanhaverbeke, W., Frattini, F., Roijakkers, N. and Usman, M. (2018), Researching open innovation in SMEs, World Scientific, New Jersey, New Jersey.

[14] Van de Vrande, V., De Jong, J.P., Vanhaverbeke, W., and De Rochemont, M. (2009), "Open innovation in SMEs. Trends, 
motives and management challenges", Technovation, Vol. 29 , No. 6-7, pp. 423-437.

[15] Danilovic, M. and Winroth, M. (2005), "A tentative framework for analyzing integration in collaborative manufacturing network settings. A case study", Journal of Engineering and Technology Management, Vol. 22, No. 1-2, pp. 141-158.

[16] Bryson, J.R. and Ronayne, M. (2014), "Manufacturing carpets and technical textiles. Routines, resources, capabilities, adaptation, innovation and the evolution of the British textile industry", Cambridge Journal of Regions, Economy and Society, Vol. 7, No. 3, pp. 471-488.

[17] Stindt, D. and Sahamie, R. (2014), "Review of research on closed loop supply chain management in the process industry", Flexible Services and Manufacturing Journal, Vol. 26, No. 1-2, pp. 268-293.

[18] Hankammer, S., Antons, D., Kleer, R. and Piller, F.T. (2016), "Researching Mass Customization: Mapping Hidden Structures and Development Trajectories", Academy of Management Proceedings, Vol. 2016, No. 1, p. 10900.

[19] Davis, S.M. (1987), Future perfect, Addison-Wesley, Reading, Mass.

[20] Gilmore, J.H. and Pine, B.J. (1997), "The four faces of mass customization", Harvard business review, Vol. 75, No. 1, pp. 91-101.

[21] Tseng, M.M. and Hu, S.J. (2014), "Mass customization", In CIRP encyclopedia of production engineering, L. Laperrière and G. Reinhart, (Eds.), Springer reference, Springer, Berlin, pp. 836-843.

[22] Reichwald, R. and Piller, F. (2009), Interaktive Wertschöpfung. Open Innovation, Individualisierung und neue Formen der Arbeitsteilung, Gabler Verlag / GWV Fachverlage $\mathrm{GmbH}$, Wiesbaden, Wiesbaden.

[23] Dellaert, B.G.C. and Dabholkar, P.A. (2009), "Increasing the Attractiveness of Mass Customization: The Role of Complementary On-line Services and Range of Options", International Journal of Electronic Commerce, Vol. 13, No. 3, pp. 43-70.

[24] Grafmüller, L.K. and Habicht, H. (2017), "Current Challenges for Mass Customization on B2B Markets. In Managing Complexity", Bellemare, J., Carrier, S., Nielsen, K. and Piller, F.T. (Eds.), Springer International Publishing, Cham, pp. 269-279.

[25] Suzić, N., Anišić, Z., Orčik, A. and Sremčev, N. (2012), "Company size and successful mass customization", $5^{\text {th }}$ International Conference on Mass Customization and Personalization in Central Europe (MCP-CE), 19-21 September, 2012, Novi Sad, Serbia, pp. 241-246

[26] Stojanova, T., Suzic, N. and Orcik, A. (2012), "Implementation of mass customization tools in small and medium enterprises", International Journal of Industrial Engineering and Management, Vol. 3, No. 4, pp. 253-260.

[27] OECD. 2000. Small and Medium-sized Enterprises: Local Strength, Global Reach, http://www.oecd.org/regional/leed/1918307.pdf.

[28] Usman, M., Roijakkers, N., Vanhaverbeke, W. and Frattini, F. (2018) "A Systematic Review of the Literature on Open Innovation in SMEs", In Researching open innovation in SMEs, Vanhaverbeke, W. (Ed.), World Scientific, New Jersey, New Jersey.

[29] Wernerfelt, B. (1984), "A resource-based view of the firm", Strategic Management Journal, Vol. 5, No. 2, pp. 171-180.

[30] Zipkin, P.H. (2001), "The Limits of Mass Customization", MIT Sloan Management Review, Vol. 42, No. 3, pp. 81-87.

[31] Piller, F.T. (2004), "Mass Customization. Reflections on the State of the Concept", International Journal of Flexible Manufacturing Systems, Vol. 16, No. 4, pp. 313-334.

[32] Trentin, A., Forza, C. and Perin, E. (2015), "Embeddedness and path dependence of organizational capabilities for mass customization and green management. A longitudinal case study in the machinery industry", International Journal of Production Economics, Vol. 169, pp. 253-276.

[33] Piller, F., Ihl, C. and Vossen, A. (2011), "", In New forms of collaborative innovation and production on the internet. An interdisciplinary perspective, Wittke, V. and Hanekop, H. (Eds.), Universitätsverlag Göttingen, Göttingen, pp. 31-63.

[34] Lacoste, S. (2016), "Sustainable value co-creation in business networks", Industrial Marketing Management, Vol. 52, pp. 151-162.

[35] Jaakkola, E. and Hakanen, T. (2013), "Value co-creation in solution networks", Industrial Marketing Management, Vol. 42, No. 1 , pp. $47-58$.

[36] Tseng, M.M. and Piller, F.T. (2003), The Customer Centric Enterprise, Springer Berlin Heidelberg, Berlin, Heidelberg.

[37] Alter, S. (2017), "Defining information systems as work systems. Implications for the IS field", European Journal of Information Systems, Vol. 17, No. 5, pp. 448-469.
[38] Lee, C.-H.S., Barua, A. and Whinston, A.B. (2000), "The Complementarity Of Mass Customization And Electronic Commerce", Economics of Innovation and New Technology, Vol. 9, No. 2, pp. 81-110.

[39] Yin, R.K. (2014), Case study research. Design and methods, SAGE, Los Angeles.

[40] Hodges, N.J. and Link, A.N. (2018), "Knowledge-intensive entrepreneurship. An analysis of the European textile and apparel industries", International Studies in Entrepreneurship, Book39, Springer, Cham, Switzerland.

[41] Peffers, K. and Tuunanen, T. (2007), "A Design Science Research Methodology for Information Systems Research", Journal of Management Information Systems, Vol. 24, No. 3, pp. 45-77.

[42] Zur Muehlen, M. and Recker, J. (2013), "How Much Language Is Enough? Theoretical and Practical Use of the Business Process Modeling Notation", In Seminal Contributions to Information Systems Engineering, Bubenko, J., Krogstie, J., Pastor, O., Pernici, B., Rolland, C. and Sølvberg, A. (Eds.), Springer Berlin Heidelberg, Berlin, Heidelberg, pp. 429-443.

[43] Becker, J., Rosemann, M. and Von Uthmann, C. (2000), "Guidelines of Business Process Modeling", In Business Process Management. Models, Techniques, and Empirical Studies, Aalst, W., Desel, J. and Oberweis, A. (Eds.), Lecture Notes in Computer Science 1806, Springer, Berlin, Heidelberg.

[44] Fettke, P. (2008), "Business Process Modeling Notation", Wirtschaftsinformatik, Vol. 50, No. 6, pp. 504-507.

[45] La Rocca, A., Moscatelli, P., Perna, A. and Snehota, I. (2016), "Customer involvement in new product development in B2B. The role of sales", Industrial Marketing Management, Vol. 58, pp. 45-57.

[46] Piller, F., Schubert, P., Koch, M. and Möslein, K. (2005), "Overcoming Mass Confusion: Collaborative Customer CoDesign in Online Communities", Journal of Computer-Mediated Communication, Vol. 10, No. 4, 39p.

[47] Sandrin, E., Trentin, A., Grosso, C. and Forza, C. (2017), "Enhancing the consumer-perceived benefits of a masscustomized product through its online sales configurator", Industrial Management \& Data Systems, Vol. 117, No. 6, pp. $1295-1315$

[48] Franke, N., Schreier, M. and Kaiser, U. (2010), "The "I Designed It Myself" Effect in Mass Customization", Management Science, Vol. 56, No. 1, pp. 125-140.

[49] Merle, A., Chandon, J.-L., Roux, E. and Alizon, F. (2010), "Perceived Value of the Mass-Customized Product and Mass Customization Experience for Individual Consumers", Production and Operations Management, Vol. 19, No. 5, pp. 503-514.

[50] Eggert, A. and Ulaga, W. (2002), "Customer perceived value. A substitute for satisfaction in business markets?", Journal of Business \& Industrial Marketing, Vol. 17, No. 2/3, pp. 107-118.

[51] Prior, D.D. (2013), "Supplier representative activities and customer perceived value in complex industrial solutions", Industrial Marketing Management, Vol. 42, No. 8, pp. 1192-1201.

[52] Candi, M. and Kahn, K.B. (2016), "Functional, emotional, and social benefits of new B2B services", Industrial Marketing Management, Vol. 57, pp. 177-184.

[53] Gosling, J. and Naim, M.M. (2009), "Engineer-to-order supply chain management. A literature review and research agenda", International Journal of Production Economics, Vol. 122, No. 2, pp. 741-754.

[54] Davies, A., Brady, T. and Hobday, M. (2007), "Organizing for solutions. Systems seller vs. systems integrator", Industrial Marketing Management, Vol. 36, No. 2, pp. 183-193.

[55] Fauska, P., Kryvinska, N. and Strauss, C. (2014), "Agile Management of Complex Goods \& Services Bundles for B2B ECommerce by Global Narrow-Specialized Companies", Global Journal of Flexible Systems Management, Vol. 15, No. 1, pp. 5-23.

[56] Nambisan, S., Lyytinen, K., Majchrzak, A. and Song, M. (2017), "Digital innovation management: Reinventing innovation management research in a digital world", MIS Quarterly, Vol. 41, No. 1, pp. 223-238.

[57] Von Hippel, E. (2001), "User toolkits for innovation", Journal of Product Innovation Management, Vol. 18, No. 4, pp. 247-257.

[58] Walcher, D. and Piller, F.T. (2011), The customization 500. An International Benchmark Study on Mass Customization and Personalization in Consumer E-Commerce, Lulu Inc., Raleigh, NC.

[59] Nightingale, P. (2000), "The product-process-organisation relationship in complex development projects", Research Policy, Vol. 29, No. 7-8, pp. 913-930. 
[60] Bettencourt, L.A., Ostrom, A.L., Brown, S.W. and Roundtree, R.I. (2002), "Client Co-Production in Knowledge-Intensive Business Services", California Management Review, Vol. 44, No. 4, pp. 100-128.

[61] Steiner, F. (2014), "Solution space development for mass customization. Impact of continuous product change on production ramp-up", Ph.D. dissertation, University of Aachen, Schriftenreihe Innovative Betriebswirtschaftliche Forschung und Praxis 413, Kovač, Hamburg.

[62] Steiner, F. and Hergenröther, I. (2014), "Modular product architectures as an enabler of the simultaneous application of a mass customisation strategy and efficient ramp-up management", International Journal of Product Development, Vol. 19, No. 4, pp. 231-253.

[63] Steiner, F. (2014), "Extending the Theoretical Framework of Mass Customization. Initial and Adaptive Solution Space Development for High-Variety Production Environments", In Proceedings of the 7th World Conference on Mass Customization, Personalization, and Co-Creation (MCPC 2014), Aalborg, Denmark, February 4th - 7th, 2014, Brunoe, T.D., Nielsen, K., Joergensen K.A. and Taps S.B. (Eds.), Lecture Notes in Production Engineering, Springer International Publishing, Cham, pp. 201-215.

[64] Piller, F.T. (2012), "Mass Customization: A Strategy for CustomerCentric Enterprises", In Customer-Driven Supply Chains. From Glass Pipelines to Open Innovation Networks, Lyons, A.C., C Mondragon, A.E., Piller, F. and Poler, R. (Eds.), Decision Engineering, Springer Verlag London Limited, s.l., pp. 71-94.

[65] Hermans, G. (2012), "A Model for Evaluating the Solution Space of Mass Customization Toolkits", International Journal of Industrial Engineering and Management, Vol. 3, No. 4, pp. 205-214.
[66] Liechty, J., Ramaswamy, V. and Cohen, S.H. (2001), "Choice Menus for Mass Customization: An Experimental Approach for Analyzing Customer Demand with an Application to a Web-Based Information Service", Journal of Marketing Research, Vol. 38, No. 2, pp. 183-196.

[67] Salvador, F., Rungtusanatham, M., Akpinar, S. and Forza, C. (2008), "Strategic capabilities for mass customization: Theoretical synthesis and empirical evidence", Academy of Management 2008 Annual Meeting: The Questions We Ask (AOM 2008), 8-13 August 2008, Anaheim, United States.

[68] Jiao, J. and Tseng, M.M. (2004), "Customizability analysis in design for mass customization", Computer-Aided Design, Vol. 36 No. 8, pp. 745-757.

[69] Zhang, L.L. (2014), "Product configuration. A review of the stateof-the-art and future research", International Journal of Production Research, Vol. 52, No. 21, pp. 6381-6398.

[70] Yip, A.L.K., Corney, J.R., Jagadeesan, A.P. and Qin, Y. (2013), "A Product Configurator for Cloud Manufacturing", In In ASME 2013 International Manufacturing Science and Engineering Conference collocated with the 41st North American Manufacturing Research Conference, Volume 2, American Society of Mechanical Engineers, Madison (WI), United States Article number MSEC2013-1250.

[71] Kotha, S. (1996), "From mass production to mass customization. The case of the National Industrial Bicycle Company of Japan", European Management Journal, Vol. 14, No. 5, pp. 442-450.

[72] Madhavaram, S. and Hunt, S.D. (2017), "Customizing business to-business (B2B) professional services. The role of intellectual capital and internal social capital", Journal of Business Research, Vol. 74, pp. 38-46.

\title{
Razvoj složenih, kastomizovanih industrijskih proizvoda u MSP mrežama: Iz perspektive kokreiranja, razvoja prostora rešenja i projektovanja informacionih sistema
}

\author{
Leontin K. Grafmüller, Stephan Hankammer, Sarah Hönigsberg, Hendrik Wache
}

Primljen (03.10.2018.); Recenziran (27.11.2018.); Prihvaćen (05.12.2018.)

\begin{abstract}
Apstrakt
Već skoro tri decenije, kastomizovana industrijska proizvodnja (MC) se opisuje kao održiv poslovni model za preduzeća u različitim sektorima. Ipak, uvođenje i uspešan rad MC pristupa je izazovan poduhvat za preduzeća svih veličina. U ovom radu, posebna pažnja se posvećuje malim i srednjim preduzećima (MSP), koja sve ćešće formiraju mreže preduzeća kako bi uspešno razvila složene, kastomizovane industrijske proizvode. lako saradnja omogućava objedinjavanje nekoliko oblasti stručnosti, međuorganizacioni razvoj postavlja izazove u mnogim sferama. Kako bismo proučili ove izazove, uspostavili smo model mrežnih poslovnih procesa razvijen sa četiri MSP iz nemačke visokotehnološke tekstilne industrije. Na osnovu dosadašnje literature o mogućnostima MC-a, procenili smo izazove MC u mrežama MSP-a otkrivene u našem modelu mrežnog poslovnog procesa da bismo ukazali na potrebu za daljim istraživanjima. U našoj studiji predstavili smo detaljnu konceptualnu analizu scenarija, zasnovanih na našem modelu mrežnog poslovnog procesa, za tri ciljne oblasti: (1) kokreacija, (2) razvoj prostora rješenja, $i$ (3) projektovanje informacionog sistema. Takođe smo ukazali na potrebu za daljim istraživanjima i naveli posledice za akademiju $i$ praksu.
\end{abstract}

Ključne reči: Kompleksnost, kokreacija, projektovanje informacionog sistema, razvoj novih proizvoda, MSP, prostor rešenja 